Cad. Benjaminianos, Belo Horizonte, v. 13, n. 2, p. 273-293 2017

\title{
A alegoria benjaminiana na corte e na bohème
}

\section{The Benjamin's allegory in the court and bohemia}

\author{
Michel Amary \\ Universidade de São Paulo (USP), São Paulo, São Paulo / Brasil \\ michel.neto@usp.br
}

Resumo: O objetivo deste artigo é apresentar como Walter Benjamin fundamenta o conceito de alegoria no Barroco alemão e na Modernidade parisiense. Para isso devese passar primeiro por uma concepção histórica do conceito de alegoria, tomando a interpretação de Benjamin sobre o debate aberto por Friedrich Creuzer. Depois, deve-se representar a alegoria nas figuras do Barroco alemão, como o soberano, o cortesão e a corte. Após, deve-se mostrar como a alegoria se apresenta nos boulevares da Modernidade nas figuras de Charles Baudelaire. Por fim espera-se, a partir dessa aproximação, marcar, na transitoriedade que a caracteriza, um diagnóstico sobre a incapacidade de transcendência e a face oculta de nosso tempo.

Palavras-chaves: Benjamin; barroco alemão; modernidade; alegoria; Baudelaire.

Abstract: The object of this article is to present how Walter Benjamin bases the concept of allegory on the German Tragic drama and the Parisian Modernity. For this, the first step is pass through a historical conception of the concept of allegory, taking the interpretation of Benjamin on the debate opened by Friedrich Creuzer. Then, one must represent the allegory in the figures of the German Tragic Drama, as the sovereign, the courtier and a court. After, one must prove how the allegory is present in the boulevards of Modernity in the figures of Charles Baudelaire. Finally, it is hoped, from this approach, to mark, in the transience that characterizes the allegory, a diagnosis about the incapacity of transcendence and the hidden face of our time.

Keywords: Benjamin; German tragic drama; modernity; allegory; Baudelaire. 


\section{Introdução}

No conjunto da filosofia da história de Walter Benjamin, a alegoria aparece como um conceito fundamental. Em sua tese de livredocência, Origem do drama barroco alemão (Ursprung des deutsche Trauerspiel), Benjamin apresenta pela primeira vez, no interior do mito e da tragédia, o conceito de alegoria como uma maneira de reestabelecer uma verdadeira historicidade; não aquela que se apresenta de maneira progressiva como sucessão de fatos, implicada causalidade e na imanência da natureza como uma história natural; mas aquela que preza por sua temporalidade e seu próprio teor histórico, manifesto na ligação arbitrária entre o passado e presente. Aquela que mostra no espelhamento de dois tempos aparentemente tão distintos, não um desejo de nostalgia e restauração de um passado distante que se quer reviver, mas as ruínas e os resquícios que insistem e perduram no tempo; a forma oculta do passado que há no presente e que, escondida, o presente não diz, mas revela. ${ }^{1} \mathrm{Na}$ discussão teórica resgatada por Benjamin, essa noção alegórica se apresenta na segunda parte de seu livro, confrontada com a ideia de símbolo, que perdurou na estética germânica desde o classicismo de J.J. Winckelmann. Aos olhos de Benjamin a ideia de beleza, claridade, luz e eternidade ligadas ao simbólico, fizeram com que os "mandarins alemães" deixassem de lado o drama barroco, repleto de ambiguidades, arbitrariedades e imagens alegóricas. A sua preocupação em dar origem ao drama trágico alemão, não se dá tanto por seu valor estético, mas principalmente, pela reabilitação da história, vislumbrada a partir da representação alegórica no cerne da dramaturgia barroca. Essa valorização do alegórico vai intermediar todo o seu pensamento chegando até a modernidade nos trabalhos sobre Baudelaire (Charles Baudelaire:

\footnotetext{
${ }^{1} \mathrm{Na}$ sua análise do drama barroco estava também implícita a relação de seu próprio tempo histórico, as conturbações do período entre guerras da República de Weimar. Vendo a impossibilidade de transcendência histórica do homem do barroco, Benjamin abre na teoria de soberania do século XVII um debate com o jurista Carl Schmitt sobre a teoria do decisionismo, peça chave na fundamentação conceitual do estado de exceção e justificação teórica para ascensão do Terceiro Reich.

${ }^{2}$ Franz Ringer chamou de 'mandarins alemães' os intelectuais do ambiente universitário, representantes de uma classe privilegiada e dominante, com autoridade para falar e formar opinião sobre aspectos culturais e políticos. CF. O declínio dos mandarins alemães. EDUSP, São Paulo, 2007.
} 
Ein Lyriker im Zeitalter des Hochkapitalismus) e as Passagens de Paris (Passagen-Werk). Neste artigo nos propomos a apresentar como Benjamin trabalha a doutrina da alegoria passando por dois momentos distintos, a representação da corte no Barroco alemão e a apresentação da bohème na Paris da Modernidade.

\section{A doutrina benjaminiana da alegoria}

Neste primeiro momento, devemos apresentar de onde veio e como se constituiu a teoria da alegoria em Walter Benjamin. O que viria a ser a alegoria? Qual a concepção que Benjamin fazia deste conceito? Por que ele se tornou tão caro à ele, a fim de querer reabilitá-lo? Como se constituiu essa retomada do termo em seu pensamento filosófico?

Ao que tudo indica, Benjamin retoma o conceito de alegoria a partir das discussões estética da modernidade em torno do simbólico, se aproximando das ideias de Georg Friedrich Creuzer. Na sua leitura de Symbolik und Mythologie der alten Völker, besonders der Griechen, Benjamin atribui a Creuzer "uma grande reflexão teórica sobre o simbolismo" que é "indiretamente, de grande relevância para a percepção do alegórico" (BENJAMIN, 2013, p. 174). Ao pensar o simbólico, Creuzer foi um dos primeiros teórico a dar uma atenção maior a subestimada alegoria, assinalando sua distância e hierarquia em relação ao alegórico de maneira temporal. A teoria do simbólico se manifestava filosoficamente pela relação entre a "aparência" e a "essência", o símbolo era uma representação, mas, como tal, acreditava-se que nele apresentava-se essencialmente o representado: o símbolo é! De tal maneira que poderíamos acusar uma confusão entre o simbólico (imagem do belo) como a própria essência do belo (o belo em si). Partindo dessa visão Classicista herdada de Winckelmann, Creuzer procura a essência daquilo que os antigos chamavam de symbola; caracterizando-a pela clareza, brevidade e beleza da forma tal como um relâmpago. O símbolo era apresentado como a própria imagem da beleza em sua natureza plástica, nele se encontra uma total identificação da imagem com o belo da natureza; é tido como uma unidade que compreende os antagonismos e as ambiguidades, mostrando-se como verdadeira essência do belo, ou seja, universal. Contudo, enquanto de um lado temos o símbolo plástico como lugar da beleza das formas, de outro, aparecia a alegoria, colocada ao lado do mito, desprezada hierarquicamente apenas como 
uma miragem de pretensão simbólica. Creuzer observa que, ao lado desse símbolo plástico e artístico que ocupa um lugar superior, há também, em sua oposição, um símbolo místico, alegórico, de natureza religiosa, que, exagerado e excessivo, "na sua busca de expressão, acabará por destruir, com força infinita da sua essência, a forma terrena, receptáculo demasiadamente frágil" (ibidem, ibidem), separando a linguagem com a representação e a imagem com a palavra. A alegoria não é aquilo que é, ela é significação e não o próprio ser, de modo a dar margem a interpretações, a ambiguidades, a confundir sentidos e significados, ela "desaparece também com a clareza da visão, e o que resta é apenas um espanto mudo" (BENJAMIN, 2013, p. 174) ou a tagarelice inexpressiva. Por essa definição, caótica, a alegoria era o lugar do mito e da natureza e não da razão e da cultura, ocupados pelo apolíneo simbólico.

A diferença entre a representação simbólica e alegórica está em que esta [alegoria] significa apenas um conceito geral, ou uma ideia, diferentes dela mesma, enquanto aquele [símbolo] é a própria idéia tornada sensível corpórea. No caso da alegoria há uma substituição... no caso do símbolo, o próprio conceito desce e integra-se ao mundo corpóreo, e a imagem fornece a si mesmo de forma não mediatizada (...) Por isso a distinção entre os dois modos deve ser procurada no momentânea, que a alegoria não conhece (CREUZER apud BENJAMIN, 2013, p. 175).

Ao apontar a diferença entre símbolo e alegoria, Benjamin consegue perceber na análise de Creuzer uma distinção temporal que, segundo sua interpretação, vai levar a uma concepção original, mais próxima ao teor de verdade dos conceitos. Ao frisar o caráter momentâneo do simbólico, que de uma hora para outra aparece como o brilho instantâneo de um relâmpago revelando o belo, também se configura o caráter histórico do alegórico, que não vem de sopetão nos chocando com sua bela aparência, mas que se constitui progressivamente em momentos diversos, dependendo da ação do tempo para se realizar. Benjamin observa que o valor de uma obra de arte não deve repousar sobre o berço esplêndido do juízo e do gosto, mas sim na apreciação do tempo histórico. A alegoria, constituída pelo caráter sucessivo do tempo, nos mostra esse teor de verdade incrustado em seu teor material sobre a obra de arte que a crítica de Benjamin já ensaiava nos escritos sobre Afinidades Eletivas de Goethe (Goethe's Wahlverwandtschaften). 
Lá, Benjamin propõe uma aproximação divergente entre teor factual (Sachgehalt), caracterizado pelo estrato empírico, material, corpóreo e a determinação da aparência sensível da obra de arte, e, seu teor de verdade (Wahrheitsgehalt), manifesto como seu estrato essencialmente histórico. $\mathrm{Na}$ interpretação simbólica vemos que "quanto mais significativo for o teor de verdade de uma obra, de maneira tanto mais inaparente e íntima estará ele ligado ao seu teor factual" (BENJAMIN, 2009, p. 12), nesta perspectiva se considera o valor de uma obra de arte quanto mais próximo estiver o conteúdo de verdade de seu teor material. No entanto, Benjamin percebe que teor de verdade e teor factual não são coincidentes, eles "separam-se na medida em que a obra vai perdurando, uma vez que este [conteúdo de verdade] se mantém oculto enquanto aquele se coloca em primeiro plano" (BENJAMIN, 2009, p. 13), em contínua progressão, enquanto a obra sobrevive no tempo preservando o seu conteúdo material, o seu conteúdo de verdade vai se perdendo e tornando-se oculto para outras épocas históricas; o âmbito sensível da obra se torna mais a vistas do que o conteúdo de verdade. De tal maneira, o conteúdo de verdade de uma obra de arte só apareceria revelado pela significação histórica que depura a materialidade codificada também historicamente. Benjamin concebe a alegoria em seu legado clássico medieval em que o conteúdo de verdade do texto é preservado pela abolição do seu sentido primeiro e literal (GAGNEBIN, 1999, p.32). No seu caráter temporal, sucessivo e fragmentário, Benjamin vê na alegoria a capacidade de arruinar aquela beleza dada pelo símbolo, que instantânea se apresenta apenas de forma ideal, aparente, relacionada ao sensível e ao material. Em sua ambiguidade e constituição temporal, a alegoria, como um outro dizer (allon + agorien) mostra o corte histórico entre esses dois estratos, entre o dito e o não dito, o evidente e o oculto, a aparência sensível e a verdade histórica.

A amplitude mundana e histórica que Görres e Creuzer atribuem a intenção alegórica é de tipo dialético na sua condição de história natural, de história primordial do significar ou da intenção. A relação entre símbolo e alegoria pode ser fixada com precisão de uma fórmula remetendo-a para a decisiva categoria do tempo (...). Enquanto no símbolo, com a transfiguração da decadência, o rosto transfigurado da natureza se revela fugazmente na luz da redenção, na alegoria o observador tem diante de si a face hippocrática da história como paisagem primordial petrificada (BENJAMIN, 2013, p. 176). 
Como categoria temporal, Benjamin inverte a percepção que se constituiu em torno do simbólico e do alegórico. "A medida de tempo da experiência do símbolo é o instante místico, no qual o símbolo absorve o sentido no âmago mais oculto" (BENJAMIN, 2013, p. 176), por sua vez, "a alegoria não está livre de uma dialética correspondente, e a calma contemplativa com que ela mergulha no abismo entre o ser figural a significação não tem nada da autossuficiência indiferente que encontramos na intenção, aparentemente afim, do signo" (BENJAMIN, 2013, p. 176). É no símbolo, ao sustentar em uma suposta unidade harmônica perfeita a coincidência entre significante e significado, que está o místico. Por sua vez, o alegórico se desenvolve historicamente no tempo expressando a dialética marcante no interior da linguagem; o alegórico não representa o signo tal qual de maneira apolínea dando visibilidade ao sentido literal, ele rompe a barreira do significado e significante mostrando sempre algo oculto e diferente do que se quer mostrar. Nisto é que consistia a depreciação do alegórico na cultura clássica alemã, uma negação que vem desde o Renascimento que, procurando o desenvolvimento da razão científica e histórica, quis dar nos seus estudos gregos a maior fidelidade possível da identidade dos antigos. "Aos olhos deste novo pensamento científico, a interpretação alegórica não oferece nenhum fundamento seguro: nascida da necessidade de conciliar o teor do texto canônico com as exigências da razão e da moral (...) ela se mostra incapaz de estabelecer a necessidade desta ligação" (GAGNEBIN, 1999, p.33), uma vez que se funda na arbitrariedade estabelecida entre significante e significado.

Em Sobre a linguagem geral e a linguagem do homem (Über Sprache überhaupt und über die Sprache des Menschen), Benjamin já tinha tratado dessa separação arbitrária entre significante e significado, a partir da ligação do ato de Criação com uma língua originária adâmica, a palavra de Deus com o ato humano de dar nome às coisas. Na sua onipotência ao criar as coisas nomeando-as, a linguagem incorpora a criação, tal como pretendia o símbolo. A coincidência entre a aparência e a coisa em si, "a relação absoluta do nome com o conhecimento só existe em Deus, só nele o nome, porque é intimamente idêntico à palavra criadora, é o puro meio do conhecimento" (BENJAMIN, 2011, p. 61); aos homens "é conferido o dom da língua, que o eleva acima da natureza" (BENJAMIN, 2011, p. 60) e o aproxima de Deus. "Deus criou o homem à sua imagem, criou aquele que conhece à imagem daquele que cria" (BENJAMIN, 2011, p. 61) e não pela palavra, de modo que deu 
ao homem a capacidade de conhecer as coisas à medida que as nomeia. Contudo, esse conhecimento pela linguagem não é um ato de criação, está já foi realizada por Deus, mas de tradução da língua muda das coisas para a linguagem do homem. O logos, o conhecimento pela linguagem não se trata de dar nome a algo que não tem, mas de traduzir a língua imperfeita das coisas para uma língua mais perfeita, próxima de Deus, que é a humana. Entretanto, essa linguagem adâmica paradisíaca do homem perde-se pela sedução da serpente, representada pelo julgamento moral, pelo juízo do que é bom e do que é mal. O pecado original é o momento de nascimento da linguagem humana onde "a palavra deve comunicar alguma coisa (afora de si mesma)" (BENJAMIN, 2011, p. 67) em que a palavra comunica o exterior. A sentença do pecado original é a perda da imediatilidade da palavra para com o conhecimento, como mero signo, a palavra vira um meio para um conhecimento que não lhe é adequado, mantendo-se a distância do significado. Nesta explicação quase metafísica, Benjamin mostra tanto a incompletude dessa relação entre representante e representado que busca um acabamento, como a transitoriedade temporal que expressa a distância entre um e outro de maneira alegórica. Nesta distância a alegoria se aprofunda para trazer, a sua maneira exagerada, uma significação renovada e aberta, que não se esgota. Assim, a alegoria não diz respeito à verdade de uma língua adâmica que é divina, mas a verdade sobre uma língua múltipla em trânsito e histórica que é a linguagem humana; a alegoria seria capaz de transmitir na transitoriedade de sentidos entre a palavra e coisa, a história, marcada pela dor desta separação, pela ruína do homem em seu castigo

Com isso, a doutrina benjaminiana de alegoria se estabeleceria assim caracterizada pela materialidade histórica apresentada pela ambiguidade de suas imagens e distanciamento entre o que se diz e o que se mostra, que revela o sentido oculto das coisas, em contraposição ao instante místico que como um milagre une essência com aparência e que ao se projetar como um trovão, com tanta luz, nos cega perante o verdadeiro significado do belo, que é histórico.

\section{A corte como expressão alegórica barroca}

No drama barroco alemão a ambiguidade alegórica entre o que se quer representar e o que se diz, é colocada na relação entre o ideal religioso e a realidade política, entre hiato entre o sagrado e o profano. A 
tragédia consegue expressar todas as antinomias de uma época marcada por guerras religiosas, pela peste negra, pela Reforma e Contrarreforma; um tempo em que o homem é fervorosamente religioso, mas se vê sozinho até mesmo para interpretar a Bíblia. Os dogmas e as certezas religiosas põem a todo momento uma provação aos homens que vacilam; o desejo de eternidade se choca com a culpa e a expiação da consciência que quer sua transcendência. $\mathrm{O}$ barroco é o tempo da primazia do sujeito, do nascimento do pensamento filosófico moderno, em que a razão quer controlar a história, mas toma-lhe uma volta, se reproduzindo como uma história natural, que ocorre pela ocasião dos fatos e dos acontecimentos e se segue, em relação de causa e efeito como eventos da natureza. ${ }^{3} \mathrm{O}$ estado de exceção aparece como imanência desse mundo político e profano como aquilo que deve ordenar o caos em que do mundo. Entre a insuficiência da razão política e necessidade da fé em um Deus que se ausentou, o homem do barroco é aquele melancólico, como o anjo alado de Albrecht Dührer que vê o tempo da história passar como significação de sua própria ruína. ${ }^{4}$

\footnotetext{
${ }^{3}$ A história natural pode ser entendida aqui como um "conceito a-histórico de história que a metafísica falsamente ressuscitada cultiva naquilo que ela denomina historicidade" (ADORNO, 2009, p. 297), isto é, a concepção da história que se desenvolve progressivamente, pondo e repondo a sua lógica causal como se fosse um caminho natural. Essa concepção de história tem suas origens na separação entre a natureza e a homem que a desencanta para dominá-la e fazer-se, ser histórico (pela dominação da natureza, de outros homens e de si mesmo), portanto remete desde o racionalismo moderno e sua ordem de mecanização more geométrica. No entanto, é com G.W. Hegel que essa separação ganha maior notoriedade na progressão histórica do sujeito como espírito absoluto para a história. No calvário que a razão percorre para instaurar a história na autorrealização da consciência de si e para si, Hegel constrói uma narrativa da história como um movimento indefinidamente progressivo, em que o espírito do mundo, em um devir que não cessa, busca a cada instante uma nova figura da consciência que desintegre a representação deste seu mundo. Nesse suposto progresso da história, o século XX viu o esclarecimento do espírito universal chegar à barbárie e ao fascismo colocando em dúvida essa perspectiva progressiva da história, preocupação que consolida a crítica da Escola de Frankfurt atenta em mostrar como esse "espírito desencantado e conservado assume os traços do mito" e "se transforma em decadência do destino" (ADORNO, 2009, p. 254), fazendo da razão história, a-histórica ou natureza.

${ }^{4}$ A gravura de A. Dührer, Melancholia I aparece diversas vezes ao longo do texto benjaminano sobre o barroco para ilustrar a melancólica incapacidade do homem barroco transcender. Essa figura do anjo alado representaria para Benjamin como representação do espírito da época.
} 
As ambiguidades históricas deste tempo entram em cena no drama barroco pela retratação da corte. A corte é o palco em que a tragédia se desenvolve. "Na corte, o drama trágico depara com o cenário eterno e natural da história" (BENJAMIN, 2013, p. 92), ao mesmo tempo em que a corte é o palco onde o Príncipe busca apoio para fugir das conspirações e causos de seu destino, é também o cenário em que a natureza se apresenta de maneira mais límpida, uma vez que é o lugar dos vícios, dos crimes, dos rebeldes. Nesse âmbito a corte aparece em suas perversidades como um inferno da terra, frequentado de soberanos a intriguistas, ela aponta todo momento para o paraíso perdido não se colocando mais como uma fronteira entre o histórico e o natural, mas o palco comum em que eles convivem, nela "não cabe à antítese entre história e natureza, mas a total secularização do histórico ao seu estado criatural" (BENJAMIN, 2013, p. 91), a história se coloca dentro de cena eternizando-se enquanto natureza, acolher o destino não traz novos conteúdo, não muda mais a ordem das coisas, apenas realiza um ciclo da natureza que se repetirá mais e mais vezes, fazendo do drama um eterno retorno. Assim, de forma alegórica, a corte nos apresenta pela secularização da história como uma volta à natureza, a impossibilidade de transcendência tal como víamos nas tragédias antigas, o espaço onde a catástrofe da tragédia e do sacrifício do herói, não muda o destino do mundo, a ordem das coisas, pelo contrário se perpetua de maneira profana como representação de um século que se faz natureza.

O drama barroco não escapava do modo em que seu tempo lia história, fazendo da teoria de soberania que se desenvolveu no século XVII um momento privilegiado da condição de superioridade do soberano do ponto de vista histórico, mas na corte, a concepção alegórica representava a fratura inserida neste conceito racionalista de histórica, expressando sua natureza. Benjamin nos mostra como desde aquela época havia uma relação muito próxima entre o drama barroco e a história, "acreditava-se que o drama trágico estava, de forma tangível e concreta, no próprio curso da história, e que a única coisa necessária era encontrar palavras" (BENJAMIN, 2013, p. 57), de modo que a figura do soberano se torna o objeto verdadeiro desse gênero literário.

O soberano representa a história. Toma em mãos os acontecimentos históricos como um cetro. E este ponto de vista nada tem de privilégio das pessoas de teatro, baseando-se antes em teorias jurídicas do Estado. (...) O conceito moderno de soberania tende para um poder executivo assumido pelo príncipe, o barroco 
desenvolve-se a partir da discussão do estado de exceção considerando que a mais importante função do príncipe é impedi-lo. Aquele que exerce o poder está predestinado de antemão a ser detentor de um poder ditatorial em situações de exceção provocadas por guerras, revoltas ou outras catástrofes (BENJAMIN, 2013, p. 59-60).

Benjamin empresta o conceito moderno de soberania que encontra na Teologia Política de Carl Schmitt ${ }^{5}$ para caracterizar o soberano como a figura intocável que deve domar o processo histórico que aparece inconstante, instável e ao acaso. As guerras, revoltas, e outras catástrofes eram oscilações do velho mundo decadente que a razão tratou de desencantar impondo ordem, ao soberano cabia abolir as incertezas pela mão forte e o controle ditatorial, deveria expurgar o mundo dos resquícios do estado de natureza do homo homini lupos. " $\mathrm{O}$ soberano como primeiro expoente da história é já quase sua encarnação" (BENJAMIN, 2013, p. 57), é a personificação da razão e da ordem que, pela ditadura, evita a

${ }^{5}$ Como já dissemos, Benjamin estabeleceu um debate com o jurista Carl Schmitt em torno do tema de estado de exceção. O debate se dá em torno da legitimidade do poder de decisão do soberano em decretar o estado de exceção. Benjamin não nega a influência de Schmitt, em correspondência diz: "constará facilmente como o livro é devedor de seu trabalho, na exposição sobre a doutrina de soberania do século XVII. Permita ainda que lhe diga que encontrei também nas suas sobras posteriores (...) e nas suas reflexões sobre filosofia política a confirmação dos caminhos das minhas investigações estéticas" (BENJAMIN, 2013, p. 294); a Origem do drama barroco já era uma réplica a Schmitt há resposta crítica que o jurista dedicou ao seu ensaio: Sobre a crítica da violência. (Zur Kritik der Gewalt). Segundo a teoria schmittiana, a lei se identifica não com a norma, mas com a decisão do legislador; no caso do século XVII, a lei como expressão do Direito estaria identificada ao arbítrio do soberano, aquele quem legisla sobre todos os homens. Nesse registro o soberano se torna a lei, mas apenas na medida em que decide sobre ela, em que ele tem o poder, não apenas para aplicá-la, mas para mudá-la, e decidir sobre sua legitimidade, validade, execução ou exclusão, à plenos poderes o soberano se mantém acima dela, governa por exceção. Nesse debate podemos inserir a ligação que Benjamin faz entre estudo o drama barroco como uma fantasmagoria da situação que vive na Alemanha, um país que tal como as tragédias seiscentistas, ao querer tardiamente se impor na história, produziu um dos maiores documentos de barbárie de nossa época.

${ }^{6}$ Referência à atribuição dada ao estado de natureza hobbesiano em que 'o homem é lobo do homem'. 
desintegração do mundo e a desordem, considerado o verdadeiro estado de exceção. Contudo, na medida em que se constituía a representação do soberano como possibilidade de romper com o contínuo da natureza e do destino pelo estado de exceção, mais expressava a tragédia da condição humana. Ao mesmo tempo:

O príncipe é paradigma do melancólico. Nada ilustra melhor a fragilidade da criatura do que o fato de também ele estar sujeita a ela. Uma das mais poderosas passagens do Pensamentos de Pascal é aquela em que ele partindo de uma reflexão análoga dá voz ao sentimento de sua época. (...) Faça-se a experiência: deixe um rei completamente só, sem nenhuma satisfação dos sentidos, sem nenhum cuidado no espírito, sem companhia, pensar em si mesmo com todo o lazer, e veremos que um rei que a si mesmo se vê é homem cheio de misérias, e que se sente como qualquer outro" (BENJAMIN, 2013, p. 147).

Como protagonista dessas "peças enlutadas", o soberano se apresenta de duas maneiras: como o déspota enquanto mão forte para manutenção da ordem e defesa do Estado, e, ao mesmo tempo, como mártir na medida em que a morte encarna o limite da sua virtude. Ao longo da tragédia a composição do soberano se alterna. O príncipe, ora temido, ora piedoso, em todas as suas ações, ele aparece em suas ambiguidades e ambivalências como "uma vítima da desproporção entre a dignidade desmedida de sua condição hierárquica e a miséria de sua condição humana" (ROUANET, 1984, p. 30). Se por um lado, à ele é atribuída a responsabilidade da história, de outro, o peso dessa responsabilidade transcende a sua humanidade, e, nas artimanhas e reviravoltas do destino, melancolicamente ele se percebe enquanto criatura. $\mathrm{Na}$ fronteira entre dois mundos, o divino e o da criatura, ele encarna o luto enquanto tirano que enfrenta as conspirações contra si, subjugando a natureza, e ao mesmo tempo está condenado enquanto mártir ao sofrimento de sua condição natural que vê a história passar como destino. Desse modo é que o drama barroco começa a narrar com tom de catástrofe o ambiente da política marcado por revolta, traições e estado de exceção, expressa em sua representação os temores, os medos e as desconfianças que humanizam e naturalizam aqueles que posam impassíveis enquanto história.

Por fim, ao lado do soberano, ocupa outro papel alegórico o cortesão que como conselheiro do soberano aparece também em um 
duplo papel, o intriguista que o trai e o santo que fiel cumpre a função destinada. "O jogo" ao qual se inscreve o drama barroco "não pode ser visto apenas como aleatório, pode também ser calculista e planejado, pensado por marionetes cujos fios são manipulados por desejos e ambições" (BENJAMIN, 2013, p. 81) o artista tem pleno controle sobre seus personagens que manipula em um terreno profano marcado por jogos de interesses e poder para realização do destino da tragédia. Não por menos, Johann Rist dizia que "quem quiser escrever tragédias (...) terá de ter um domínio tão perfeito sobre a arte de governar como a da sua própria língua materna" (BENJAMIN, 2013,p. 90) e nenhum personagem encarna melhor essa condição do que o cortesão. Como conselheiro do soberano, ele é "todo inteligência e vontade" correspondente ao ideal de estadista cunhado por Maquiavel, ele "assente em fatos, tem o fundamento nestes conhecimentos, que entendem que o homem como uma força da natureza e ensinam a dominar os afetos através da mobilização de outros afetos" (BENJAMIN, 2013, p. 95-96), representam o domínio da ciência política, do pensamento racional que julga desprovido das emoções que controla de uma maneira geral, tanto para evitar as ameaças a ordem política assistindo o soberano, quanto para traí-lo com intrigas. Benjamin percebe que do mesmo modo que o estado de exceção no soberano quer restaurar a ordem sobre a instabilidade da natureza história, no cortesão que como um estoico controla o domínio dos afetos, "pode ser visto como um estado de exceção da alma" (BENJAMIN, 2013, p. 70). "A lucidez sem ilusões do cortesão é para ele próprio uma fonte de profundo sofrimento e ao mesmo tempo, devido ao uso que ele dela pode fazer a qualquer momento, perigosa para os outros" (BENJAMIN, 2013, p. 97), de um lado o cortesão, que não se deixa enganar pelos homens, apresenta, na renúncia das paixões, a sua santificação, a santificação de um deus cartesiano que ao não conseguir unir a alma com o espírito, a ambivalência entre o seu caráter divino e a sua condição de criatura, encarno o sofrimento e o luto próximo ao do soberano que, de outro lado, trai. Constituído a imagem do relojoeiro que marcou o racionalismo do século XVII, que interfere nos mecanismos do Estado para ordenar o mundo harmonicamente, "a intriga marca o ritmo dos segundos que capta e fixa o curso dos acontecimentos históricos" (BENJAMIN, 2013, p. 97), é nem nome da fidelidade de seu compromisso assumido com a ordem harmônica do mundo, ele trai o Príncipe que vê em paixões e arrogâncias, mas ao mesmo tempo, ao traí-lo cumpre o seu destino e encarnando a 
catástrofe natural. Desse modo vemos mais uma vez nas tramas alegóricas do teatro barroco "o espetáculo sempre renovado da ascensão e queda dos príncipes, ou da constância de uma virtude inabalável, não se apresentam aos autores tanto como moralidade, mas antes como a faceta natural do processo histórico, essencial na sua permanência" (BENJAMIN, 2013, p. 86), o drama segue como uma crônica que apresenta as maquinações por poder sem reconhecer o heroísmo nem no monarca, nem em seus depositores; a história passa a ser uma sucessão de acontecimentos que se repetem como se seguissem a orientação natural do mundo.

No processo de fragmentação de seu mundo, vemos a alegoria apresentar no distanciamento entre o corpo político do soberano e a sua descoberta criatural, entre a fidelidade infiel do conselheiro, santo e intriguista, da história como natureza, a alegoria apresenta de forma melancólica a dissolução do sujeito moderno. Por isso, como representação desse sujeito que se quer histórico é caracterizado pela sua indecisão, pela sua incapacidade de transcendência e significação, ela mesma expressa essa falta de certeza e arbitrariedade na formação dos sentidos, correndo o risco, até mesmo, de trair a si própria e não dizer mais nada. Nada melhor representa o barroco do que a morte.

\section{A bohème como expressão alegórica da Modernidade}

$\mathrm{Na}$ Modernidade novos personagens entram em cena. Saem o soberano, o cortesão, a corte. Entram o flâneur, o conspirador profissional e a bohème. Os cadáveres, os esqueletos e, sobretudo, a melancolia ganham novos adereços nas representações alegóricas de Charles Baudelaire. O aparecimento da industrialização capitalista, o estranhamento do sujeito consigo mesmo e o produto de seu trabalho, a objetificação do sujeito que fazia de sua autonomia apenas uma fantasmagoria, transformam vida moderna que, por sua vez, deixa de ser regida pela liberdade da razão para ser depositada nas leis de mercado. Nessa sociedade pragmática e finalista, os artistas perderam seus espaços; agora eram trapeiros que, marginalizados, corriam atrás de signos da cidade para se salvar; eram esgrimistas que deferiam seus golpes sobre o vazio do mundo. Baudelaire é o retrato do melancólico em um mundo em que a mercantilização é onipotente, em que a mercadoria se humaniza e tudo está à venda. Se "a alegoria barroca vê o cadáver apenas de fora. Baudelaire vê também de dentro" (BENJAMIN, 2015, p. 182), ele representa o herói moderno 
vestido de luto, vestindo o terno preto de "uma época que sofre e carrega sobre os ombros negros e magros o símbolo de uma eterna tristeza (...) enquanto expressão de um estado de alma público representado numa infinita profissão de gatos-pingados políticos, eróticos e privados. Todos celebramos um enterro qualquer." (BENJAMIN, 2015, p. 79), uma época de luto em que a aceleração do tempo e das metrópoles não eliminam o tédio, mas que a multidão desaparece com a individualidade, distanciando o homem de si mesmo; em que o progresso promete o novo, mas que a maquinaria e as mercadorias não passam da reprodução do mesmo. "O conceito de progresso tem de assentar na ideia de catástrofe. Que as coisas continuem como estão é isso a catástrofe" (BENJAMIN, 2015, p. 181), essa é a tragédia do moderno que o poeta, melancolicamente, apresenta como alegoria; este é o spleen que reifica o tempo e transforma, pela sensação idiossincrática de eterno retorno e catástrofe permanente, a história, como um fóssil, petrificada.

Na Modernidade a cidade se torna o espaço ocupado anteriormente pela corte. Nela se caracterizavam o boulevard onde o literato era integrado ao modelo consumista da sociedade. Nas suas passagens, "era no boulevard que ele (o literato) tinha seu reservatório de incidentes, de anedotas e de boatos" (BENJAMIN, 2015, p. 30) e sua relação com colegas de boa vida. O boulevard era o espaço onde o poeta, como um flanêur, passava seu tempo, um tempo que se manifestava simultaneamente como um tempo de ócio, caracterizando como lugar reservado da criação do artista, como também, um tempo de trabalho, assimilado pela produtividade desta sociedade. Como flanêur, o autor apresenta o desejo do ócio que se reverbera como uma postura de resistência heroica frente à ética protestante do capitalismo, mas, ao mesmo tempo, também está expresso nele o desejo pelo reconhecimento como poeta. Benjamin representa a situação do homem de letras como este que "se dirige ao mercado dizendo a si mesmo que vai ver o que passa; mas na verdade já anda a procura de um comprador" (BENJAMIN, 2015, p. 36). Na modernidade o homem das artes "comporta-se como se tivesse aprendido com Marx que o valor de cada mercadoria é determinado pelo tempo de trabalho socialmente necessário para a sua produção" (BENJAMIN, 2015, p. 30) de tal maneira, ele percebe que "o valor da sua própria força de trabalho adquire qualquer coisa de quase fantástico em face o dilatado ócio que, aos olhos do público, é necessário para sua realização plena" (BENJAMIN, 2015, p. 30), o escritor deixa de lado a 
fantasia que o ócio lhe proporcionava para assumir a fantasmagoria da mercadoria. Enquanto ainda há no imaginário social a percepção de seu ócio criativo, nos porões de Paris, grandes nomes como Alexandre Dumas e Victor Hugo, empregavam pobres literatos em uma produção fordista de artigos. Na Paris de Baudelaire, o romance e a poesia tinham mesmo se tornado mercadoria. Assim na cidade moderna, como no barroco, "a visão alegórica está baseada na desvalorização do mundo aparente" (GAGNEBIN, 1999, p. 39), marcado no caso pelo ócio apresentado como trabalho, pela arte apresentada como mercadoria.

Frente à apropriação da arte como objeto com valor comercial, mas sem dignidade artística, do literato como negociante e não como gênio artístico, Benjamin destaca na cidade das luzes - das passagens, dos bulevares e das aparências - a escuridão e a sombra da Bohème na Paris do Segundo Império, este sim o espaço alegórico da degradação, do despedaçamento social, da ruína, dos vícios, da ralé, da prostituição, da conspiração. Como forma alegórica, a bohème reverbera tudo o que a ideia de progresso e de desenvolvimento capitalista faz oculto: dos discursos de autonomia do sujeito, do individualismo liberal, nessa esfera encontramos "toda espécie de gente duvidosa" (BENJAMIN, 2015, p. 13), uma "massa indefinida, dissoluta e dispersa" (BENJAMIN, 2015, p. 14) caracterizada por conspiradores de ocasião e profissionais. Baudelaire se ocuparia principalmente destes conspiradores profissionais que, longe de participar das reuniões como um apelo do chefe, vivam mais pela conspiração do que pela própria revolução; para eles "a única condição da revolução é poder organizar de forma satisfatória a sua própria conspiração" (BENJAMIN, 2015, p. 15). Com preocupação única na conspiração, o conspirador profissional só se interessa pela realização de seu plano, pela concretização da sua fantasia, mas não pela luta de classes ou melhoria de sua condição social. O seu comprometimento com sua panóplia de projetos permite que ao mesmo tempo em que se mostre revolucionário, também sirva ao próprio império, como mostra a ascensão de Napoleão III no Dezoito de Brumário. Da Sociedade de 10 de dezembro ao período imperial, Napoleão III utilizou-se durante todo o tempo de práticas conspirativas constituídas a partir da indeterminação da massa. "Proclamações surpreendentes e secretismos, rompantes bruscos e ironia impenetrável fazem parta da razão de Estado do Segundo Império. E os mesmos traços se encontram nos escritos teóricos de Baudelaire" (BENJAMIN, 2015, p. 14) que pode colocar-se tanto como um defensor da burguesia no Salão de 1846 como 
colocar-se ao lado dos pobres em As flores do mal. Esta falta de coerência, a arbitrariedade de sentido, a duplicidade e contradição de um conspirador, ora revolucionário e ora conservador, é que ganha vestes alegóricas no estilo provocador de Baudelaire:

Digo 'Viva a revolução!' como poderia dizer 'Viva a destruição!, Viva a expiação! Viva o castigo! Viva a morte! 'Seria feliz, não apenas como vítima; também o papel de carrasco não me desagradaria - para sentir a revolução de ambos os lados! Todos temos no sangue espírito republicano, tal como temos a sífilis nos ossos; estamos infectados de democracia e sífilis" (BENJAMIN, 2015, p. 14).

Como no barroco o pathos do alegórico é a destruição e a morte. O homem moderno almeja a revolução como o do barroco almejava a transcendência, mas na imanência do mercado, do capitalismo que agora se faz como uma religião impondo-se com seus rituais diários contaminando, inclusive, a esfera do político, o futuro, tal como o passado, só pode ser percebido como destruição, como castigo, como morte. Ao poeta que conclama a arte pela arte vestindo os trajes do discurso burguês e liberal de autorregulação e livre comércio, mas que, ao mesmo tempo, não quer subordinar sua criação a um sistema de mercadorias; que tanto vende a sua obra como recusa a apreensão da sua arte apenas como um objeto; que se percebe pequeno-burguês, mas e se vê excluído, desprezado, e incompreendido pela sociedade, só cabe a destruição, fazer das obras de arte ruínas a mostrarem suas fantasmagorias. Aqui podemos lembrar novamente do papel que a alegoria desenvolve na crítica no ensaio sobre as Afinidades Eletivas de Goethe. Benjamin diz que:

Se, por força de um símile, quiser-se contemplar a obra em expansão como uma fogueira em chamas vívidas, pode-se dizer então que o comentador se encontra diante dela como o químico, e o crítico semelhantemente ao alquimista. Onde para aquele apenas madeira e cinzas restam como objetos de sua análise, para este tão somente a própria chama preserva um enigma: o enigma daquilo que está vivo (BENJAMIN, 2009, p. 13-14).

Ao tomarmos a obra de arte como uma fogueira, a sua materialidade desaparece como cinzas e madeiras, mas tomada ainda formação, é na enigmática chama do alquimista que se encontra seu valor de verdade, seu valor histórico. É a morte, a destruição, da falsidade deste mundo de 
aparências é que mostrará no esqueleto confuso da alegoria a apreensão pela verdade história e a busca por um outro tempo. Não por menos Benjamin destaca uma passagem de Karl Marx sobre Louis Auguste Blanqui e os conspiradores profissionais, segundo o qual, eles são "os alquimistas da revolução e partilham com os antigos alquimistas a desordem mental e a estreiteza das ideias fixas" (BENJAMIN, 2015, p. 19); a conotação marxiana negativa sobre os conspiradores profissionais ganham em Benjamin outro sentido quando se refere à Baudelaire. Como alquimista que mantém a chama viva encontrando nas ruínas e destruição o teor de verdade da obra de arte, aquilo que se mantém historicamente queimando e resiste às fantasmagorias e às aparências, a desorientação é própria da alegoria. A imagem de Baudelaire aparece cindida espontaneamente de um lado como "a babel de enigmas da alegoria, no outro, o secretismo exagerado do conspirador" (BENJAMIN, 2015, p. 19) em seus planos mirabolantes de revolução. Baudelaire personificava ao mesmo tempo os vapores dos grupos das tabernas em seus ritos conspiratórios, onde o conspirador subalterno se sentia em casa e os deserdados alimentavam "seus sonhos de vingança e glórias futuras" (BENJAMIN, 2015, p. 20), e a conspiração na cólera encarniçada das barricadas com as "mágicas pedras, que da calçada, que se erguem para altura como fortalezas" (BENJAMIN, 2015 , p. 17) capaz de "arrombar as deste mundo e deixar em ruínas as suas construções harmoniosas" (BENJAMIN, 2015, p. 168); tanto os revolucionários dirigentes que doutrinadores não conhecem as mãos que atiram pedras como os enigmas alegóricos pelo olhar do trapeiro que, em sua "revolta mais surda", caminha e recolhe as ruínas da cidade, a desvendando das aparências do capitalismo.

$\mathrm{Na}$ poesia Baudelaire, ao lado dos conspiradores profissionais e dos trapeiros, alquimistas da revolução, podia se encontrar outra figura enigmática, o satanismo. Muito próximo da contradição posta nos conspiradores, no satanismo baudelairiano poderíamos ver de fato um significado oculto que se mostrava alegórico. O terreno do profano representado por Satã não deve ser tomado em seu sentido primeiro, o diabo tem duas faces. Satanás é visto ao mesmo tempo como a causa de todos os males como também uma grande vítima derrotada que incorpora a posição dos inconformistas. Rejeitado do Reino dos Céus, ele constitui uma classe rebaixada de anjos, tal como o proletariado representado no poema Abel e Caim como a "classe de homens inferiores, nascida do cruzamento de bandidos e prostitutas" (BENJAMIN, 2015, p. 23). Anjo 
caído, Lúcifer, aparece como confessor dos conspiradores uma vez que "depois da derrota do proletariado nas lutas de junho, o protesto contra as ideias burguesas de ordem e honestidade ficou mais bem guardado nas mãos dos dominadores do que na dos oprimidos" (BENJAMIN, 2015, p. 25); como tal ele confunde as classes mais altas que bradavam "Só a cabecilha da Sociedade 10 de Dezembro ainda pode salvar a sociedade burguesa! Só o roubo pode salvar a propriedade, o perjúrio, a religião, a bastardia, a família, a desordem a ordem" (BENJAMIN, 2015, p. 26). Mas, também, nas festas da corte, ele aparece como o intriguista demoníaco, contaminando do cinismo as figuras pequeno-burguesas que caem na ilusão da bohème dorée acreditando concretizar seus sonhos e a liberdade prometida. Como um intrigante do inferno o Demônio tem sua morada perto dos boulevard onde seduz para o pecado, para a luxúria, a fofoca, o consumo. Assim, "Satanás não fala apenas para os de baixo, mas também para os de cima" (BENJAMIN, 2015, p. 25), ardilosamente em satanás cabia o tom cínico das classes abastadas nos de baixo como também o tom rebelde das classes menos favorecidas nos de cima.

Por fim, nas contradições mais evidentes entre os boulevard e a bohème, do artista entre o desejo de ócio e de reconhecimento, entre os conspiradores profissionais que vivem a revolução dos dois lados, entre o profano diabo que serve tanto aos de baixo como aos de cima está impressa claramente o materialismo dialético histórico da modernidade, a luta de classes. No entanto, ela não se revela ao modo de Marx como uma etapa progressiva e transitória da história que levaria, em sua contradição, para outra etapa do desenvolvimento histórico. Em suas Teses sobre o conceito de história Benjamin já tinha se manifestado contra essa visão positivista do materialismo histórico. Não será ela mais o motor da história! Diz ele: "o materialista histórico não pode renunciar ao conceito de um presente que não é transição, mas o qual o tempo ficou imóvel. Pois esse conceito define exatamente o presente em ele descreve a história para si mesmo" (BENJAMIN, 2010, p. 128), o historicismo do materialismo histórico era homogêneo e vazio tempo linear tal como aquela historiografia positivista e burguesa que se perpetuava na ideia de Modernidade. Uma nostalgia do passado pela saturação do tempo de agora, o 'salto do tigre' (Tigersrpung) que interpõe a construção e o desenvolvimento do tempo presente com o lugar passado, que faz ecoar as vozes dos heróis e dos derrotados. "O spleen introduz séculos entre o instante presente aquele que acabou de ser vivido. É ele, que, 
incansavelmente produz a 'antiguidade"' (BENJAMIN, 2015, p. 158) no presente; aquela que permitiu o retorno de Roma por Robespierre, e a Revolução Francesa por Blanqui e da Comuna de Paris por Baudelaire. Uma tentativa de transformação fracassada na medida em que o salto em direção ao passado nos mantém presos na imanência da antiguidade. Por isso, "se se pode dizer que a vida moderna é, em Baudelaire, o reservatório das imagens dialéticas, nisso se inclui o fato de ele se relacionar com a vida moderna do mesmo modo que o século XVII com a antiguidade" (BENJAMIN, 2015, p. 153), isto é, com o olhar melancólico sobre o passado que revela um mundo em completa desagregação.

O que no barroco chamaríamos de transcendência, na modernidade colocaríamos como revolução; ambas as perspectivas frustradas aos seres humanos de seus respectivos tempos. Como no drama barroco em que o passado era articulado, na necessidade da fé, como uma busca de romper com o destino, mantendo-se na imanência da história natural, no caso vertente de Baudelaire, é fixada a ideia de passado na tentativa de quebrar a ordem caleidoscópica desse processo histórico, que, acaba por instaurar um eterno retorno do novo numa falsa ideia de continuidade e progresso que apenas mantém as coisas em seu devido lugar, produzindo assim, a famosa imagem dialética do filme $O$ Leopardo: ${ }^{7}$ é preciso que tudo mude para que tudo fique como está. Benjamin vê, a partir de Baudelaire, as raízes do equívoco da modernidade que confunde o novo com o moderno. A modernidade crê se dirigir em direção ao futuro, mas está acorrentada ao passado como nova Antiguidade, o caráter alegórico de Baudelaire traz como sentido oculto a imobilidade tempo presente e não do movimento e da transitoriedade. O que se revela é uma relação de fetichismo do próprio tempo da Modernidade em sua oposição com o antigo, em que a mudança só pode vir com a destruição do processo dessa linha do tempo contínua da história, que segue como em uma esteira na linha de montagem, produzindo um fato atrás do outro em que o novo aparece como um sempre igual. $\mathrm{O}$ artista é o âmago desta representação alegórica. Em $O$ pintor da vida moderna Baudelaire retrata Constantin Guys, em sua correria cotidiana, como dilema da posição do artista moderno na sociedade industrial capitalista: sempre um passo à frente de seus contemporâneos, mas atrasado com relação a novidade. Na maneira em que Baudelaire apresenta o tempo histórico

\footnotetext{
${ }^{7}$ VISCONTI, Luchino. Il Gattopardo, 1963.
} 
da Modernidade, podemos observar a tradição da ruptura, marcada pela sucessão de rápidas interrupções e um eterno começar de novo, própria da circulação de mercadoria no capitalismo em que tudo é fugaz, descartável e o novo sempre tem que se sobrepor. Na Modernidade tudo que é novo, logo transforma-se em seu contrário, de modo que a barreira do tempo se torna imóvel e instransponível, uma vez que ela se torna eterna transitoriedade que não chega a lugar nenhum. Ao mesmo tempo, o tempo se constrói e se destrói, se materializa e logo já se esvai; a única imagem que permanece é a miséria continua. Essa eterna transitoriedade é o equivalente a incapacidade de decisão que vemos no barroco, tanto a intervenção do artista como a atitude do soberano frente ao domínio do tempo histórico aparecem deslocada e ineficaz, "a salvação corresponde a um cedo demais ou a um tarde demais" (BENJAMIN, 2015, p. 181). Desse modo, a alegoria moderna se conecta com a alegoria barroca; se no barroco a alegoria poderia perder-se em tagarelice não produzindo mais sentido algum; na Modernidade de Baudelaire ela mostra a apreensão deste tempo histórico em que o próprio tempo não tem tempo de se significar, em que perdemos a própria dimensão temporal do tempo. A história que era natureza no barroco, no capitalismo industrial torna-se mera mercadoria. Agora time is money!

\section{Referências}

ADORNO, T.W. Dialética Negativa. Rio de Janeiro: Zahar, 2009.

BAUDELAIRE, C. O pintor da vida moderna. Belo Horizonte: Autêntica, 2010.

BENJAMIN, W. As afinidades eletivas de Goethe. In: Ensaios reunidos: escritos sobre Goethe. São Paulo: Editora 34, 2009.

BENJAMIN, W. Baudelaire e a modernidade. Belo Horizonte: Autêntica, 2015.

BENJAMIN, W. Origem do drama trágico alemão. Belo Horizonte: Autêntica, 2013.

BENJAMIN, W. Sobre a linguagem geral e a linguagem do homem. In: Escritos sobre mito e linguagem. São Paulo: Editora 34, 2011. 
BENJAMIN, W. Sobre o conceito de história. In: Walter Benjamin: aviso de incêndio. São Paulo: Boitempo Editorial, 2010.

BOLLE, W. Fisiognomia da Metrópole Moderna: representação da História em Walter Benjamin. São Paulo: Edusp, 1992.

CASTRO, C. A alquimia da crítica: Benjamin e As afinidades eletivas de Goethe. Rio de Janeiro: Paz e Terra, 2011.

GAGNEBIN, J. Alegoria, morte e Modernidade. In: História e Narração em Walter Benjamin. São Paulo: Perspectiva, 1999.

ROUANET, S. Origem do drama barroco alemão. São Paulo: Brasiliense, 1984.

Recebido: 26 de fevereiro de 2018. Aprovado em: 06 de fevereiro de 2018. 